\title{
Ultrastructural Study of the Alimentary Tract of Two Reptilian Species the Lizard Scincus scincus and the Snake Natrix tessellata
}

\section{Rasha E Abo-Eleneen ${ }^{1}$, Ahlam M El- Bakry ${ }^{1 *}$ and Ahmed M Abdeen ${ }^{2}$}

${ }^{1}$ Department of Zoology- Faculty of Science, Beni-Suef University, Egypt

${ }^{2}$ Department of Zoology- Faculty of Science- Mansoura University, Egypt

\begin{abstract}
The ultrastructural difference of the alimentary tract of the insectivore, Scincus scincus and the carnivore, Natrix tesstellata was described by using scanning and transmission electron microscopy. The oesophagus of $S$. scincus with many prominent longitudinal folds while in $N$. tessellata it has many primary longitudinal folds and secondary ramification. The oesophageal epithelium of both species has numerous goblet cells. The mucosal epithelial cells in both species contain large nucleus, endoplasmic reticulum, lysosomes and some vacuoles. Stomach had a meshwork of primary folds in S. scincus and it forms various folds forming many discrete, irregular pockets in $N$. tessellata. The mucosal cells in the stomach of $S$. scincus have many secretory granules while in $N$. tessellate it provided with numerous mucinogen granules in the gastric columnar cells. In S. scincus, the intestinal mucosa with many primary folds but it appeared as longitudinal secondary mucosal folds in Zig-Zag pattern enclosing a number of concavities in $N$. tessellata. The intestinal mucosal cells in both species consisted of regularly formed microvilli. There were numerous goblet cells in the intestine of both species. In conclusion, structural variation of the alimentary tract in the two species examined was related to difference in feeding habits.
\end{abstract}

Keywords: Reptiles; Alimentary tract; SEM; TEM

\section{Introduction}

The digestive system is as important as food is to survival in animals. The anatomical characteristics of this system are dependent upon the food, habitat and nutritional status of the organism [1]. In reptiles, the digestive system contains all the structures present in other higher vertebrates, from the oral cavity to the cloaca. The oral cavity is lined by mucous membrane made by non-ketatinized stratified squamous epithelium with salivary glands distributed in the submucosa [2].

In reptiles, the first vertebrates to adapt completely too the terrestrial life, the oesophagus shows adaptive modifications from group to group, the stomach varies in shape and the intestine may be highly convoluted as in turtles or relatively straight as in snakes to facilitate absorption, secretion and excretion [3-6].

The ultrastructural studies of the Gastrointestinal tract have been widely used to provide a detailed anatomical description that betters to understanding the operation of this system as in Typhlopid Snake Rhamphotyphlops Braminus and Scincus scincus [7,8]. Carrassón \& Matallanas [9] used SEM (Scanning electron microscope) to study the digestive tract in Dentex dentex; while Imtiyaz \& Ashok [10] used the same technique to examine the intestinal tract of Schizothorax curifrons.

The present work aims to study the ultrastructural features of the digestive tract of two reptilian species Scincus scincus and Natrix tessellate, inhabiting different locations and with different mode of feeding, in order to increase current knowledge in basic structures of the reptilian alimentary tract.

\section{Materials and Methods}

\section{Sample collection}

5 specimens of both species, Scincus scincus and Natrix tessellata were used. The first species was capture from sandy desert areas of Sinai and it feeds on a variety of insects while the second one is collected from irrigated canals of Faiyum. It feed on fish and amphibian. The two species were dissected and oesophagus, stomach and intestine were removed. The animals were anaesthetized and decapitated according to the international protocol for biomedical Investigation with Human Being and Animals.

\section{Scanning electron microscopy}

The dissected oesophagus, stomach and intestine were cut into pieces and fixed in glutraldehyde in $0.1 \mathrm{M}$ cacodylate buffer. The specimen were post-fixed in a solution of $1 \%$ osmium tetroxide in $0.1 \mathrm{M}$ sodium cacodylate buffer for one hour, and washed several times in the $0.1 \mathrm{M}$ sodium cacodylate buffer. The tissues were dehydrated through either acetone or alcohol series, critical point drying and platinum-palladium ion-sputtering were applied. The specimens were then investigated by scanning electron microscopy (JSM -5400LV; JEOL).

\section{Transmission Electron Microscope (TEM)}

Small fragments of the oesophagus, stomach and intestine were fixed in fresh $3 \%$ glutaraldehyde in $0.1 \mathrm{M}$ cacodylate buffer $(\mathrm{Ph} 7.2)$ for $4 \mathrm{~h}$. Afterwards, the specimens were post-osmified in $0.1 \mathrm{M}$ cacodylate buffer ( $\mathrm{Ph} \mathrm{7.2)}$ for $2 \mathrm{~h}$. They were then washed again in the buffer, dehydrated, and embedded in epoxy-resin araldite mixture. Semithin sections were cut by ultramicrotom, stained with toluidine blue, then examined. Ultrathin sections were cut using a diamond knife and stained using uranyl acetate and lead citrate, then examined by $\mathrm{Cx} 100$ transmission electron microscope (JEOL, operated at an accelerating voltage of $60 \mathrm{Kv}$ ).

*Corresponding author: Ahlam M. El- Bakry, Department of ZoologyFaculty of Science, Beni-Suef University, Egypt, Tel: 01282812572; E-mail: amalbakry2@yahoo.com

Received September 24, 2014; Accepted October 27, 2014; Published October 29, 2014

Citation: Abo-Eleneen RE, El- Bakry AM, Abdeen AM (2014) Ultrastructural Study of the Alimentary Tract of Two Reptilian Species the Lizard Scincus scincus and the Snake Natrix tessellata. J Cytol Histol S4: 010. doi:10.4172/2157-7099.S4-010

Copyright: (C) 2014 Abo-Eleneen RE, et al. This is an open-access article distributed under the terms of the Creative Commons Attribution License, which permits unrestricted use, distribution, and reproduction in any medium, provided the original author and source are credited. 
Citation: Abo-Eleneen RE, El- Bakry AM, Abdeen AM (2014) Ultrastructural Study of the Alimentary Tract of Two Reptilian Species the Lizard Scincus scincus and the Snake Natrix tessellata. J Cytol Histol S4: 010. doi:10.4172/2157-7099.S4-010
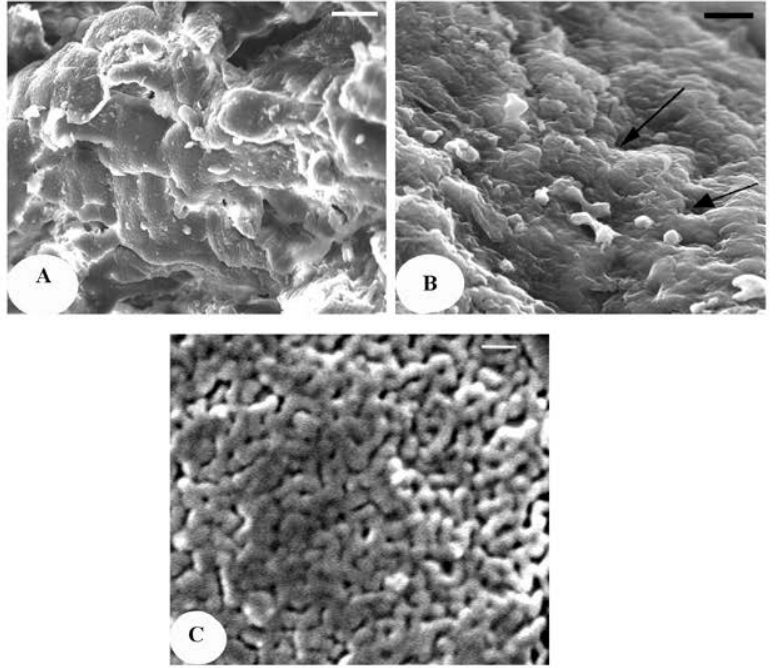

Figure 1: SEM micrograph of the oesophagus of Scincus Scincus, showing (a) many prominent longuitudinal folds. (Scale bar, $50 \mu \mathrm{m}$ ). (b) many goblet cells (arrows) Scale bar, $50 \mu \mathrm{m}$. (c) Surface wavy microridge (Scale bar, $1 \mu \mathrm{m})$.
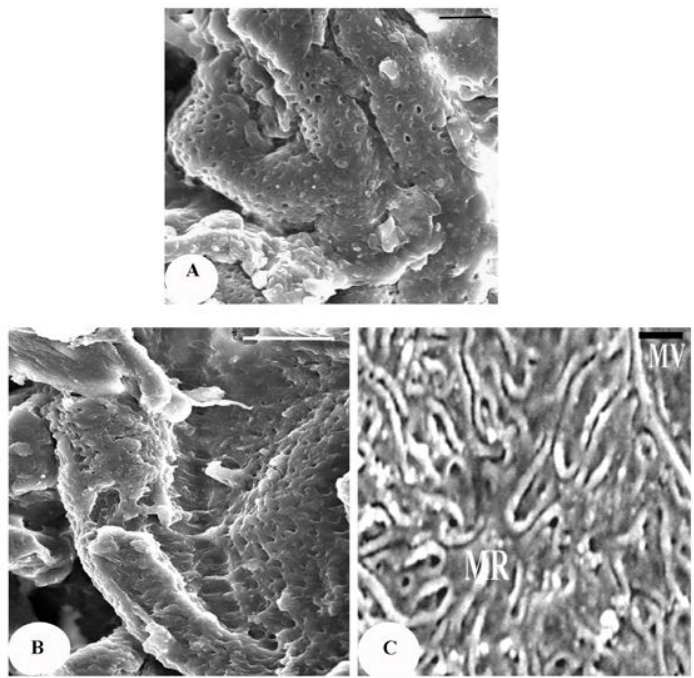

Figure 2: SEM micrograph of the oesophagus of Natrix tessellata, showing (a) primary and secondary folds. (Scale bar, $50 \mu \mathrm{m}$ ). (b) many goblet cells (Scale bar, $20 \mu \mathrm{m})$. (c) apical fingerprint-like microridge(MR) alternates with microvilli (MV) in some regions (Scale bar, $1 \mu \mathrm{m}$ ).

\section{Results}

SEM observation showed that, the oesophageal mucosal surface in $S$. scincus was provided with many prominent longitudinal folds leaving long furrows in between them. Many circular opening of goblet cells and well-defined wavy micriridges were also detected (Figure 1ac). While in $N$. tessellata, the oesophageal surface has many primary longitudinal folds of different sizes and secondary ramification (Figure 2a). Some pocket marks representing the luminal surface of goblet cells were found in between the cell junctions (Figure $2 b$ ). The superficial oesophageal epithelium provided with fingerprint-like microridge alternates in some regions with apical microvilli (Figure 2c).
By TEM, The oesophageal mucosal cells of $S$. scincus, containing oval-shaped nucleus oriented parallel to the epithelial surface (Figure 3a). Some mitochondria, vacuoles, endoplasmic reticulum and lysosomes were observed (Figures $3 \mathrm{a}$ and $3 \mathrm{~b}$ ). Numerous goblet cells are found in the mucosa of stratified epithelium occupying the whole length of the oesophagus (Figure 3c). On the other hand, the mucosal cells in the oesophagus of $N$. tessellata, with an oval nucleus (Figure $4 a)$. Lysosomes, vacuoles and numerous mitochondria were found scattering in the cytoplasm of the epithelial cells (Figure 4a and 4b). Goblet cells and microvilli were also observed (Figure 4c).

In S. scincus, stomach had a meshwork of primary folds by SEM
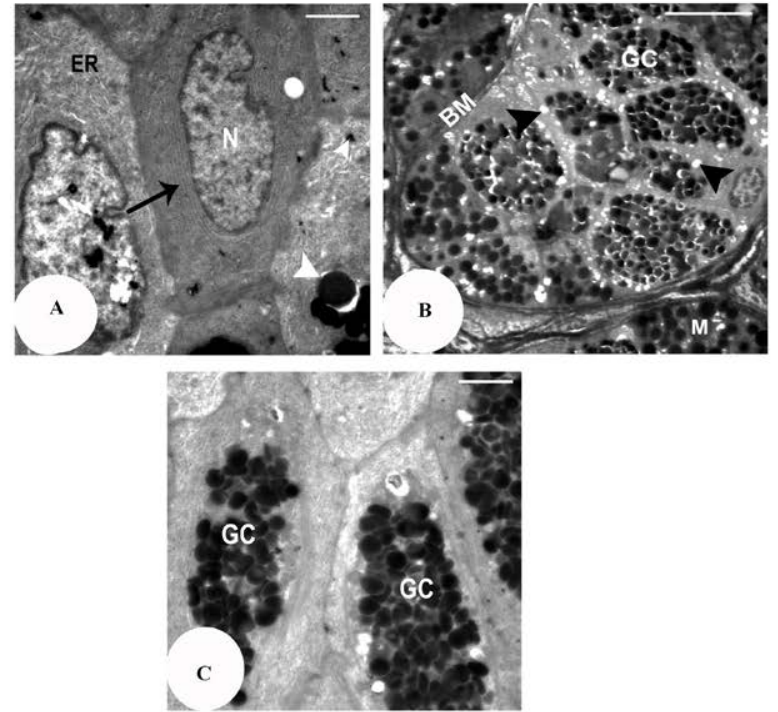

Figure 3: TEM micrograph of the oesophagus mucosal cells of Scincus scincus, showing (a) large nucleus (N) (arrow), endoplasmic reticulum (ER) and lysosomes (arrowhead). (Scale bar, $2 \mu \mathrm{m}$ ). (b) the basal membrane (BM), mitochondria (M) and vacuoles (arrowhead). (Scale bar, $10 \mu \mathrm{m})$. (c) numerous goblet cells (GC). (Scale bar, $2 \mu \mathrm{m}$ ).
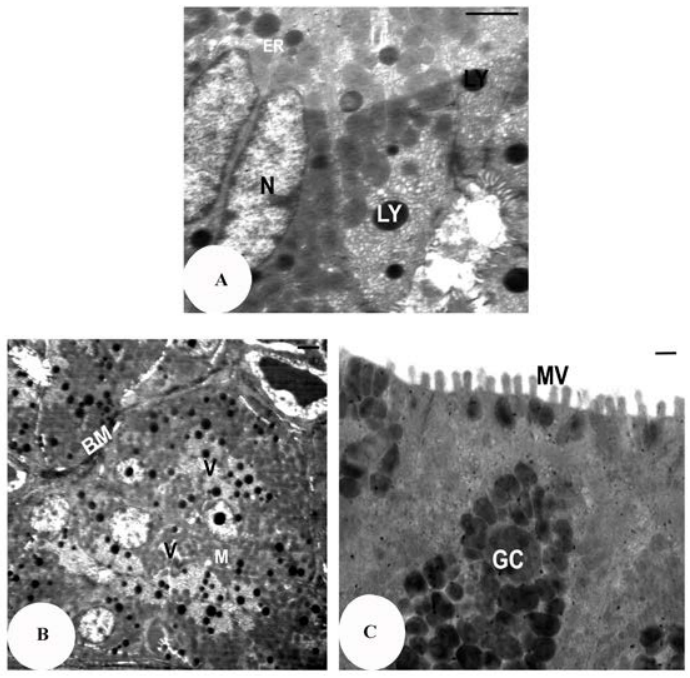

Figure 4: TEM micrograph of the oesophagus mucosal cells of Natrix tessellata, note, (a) nucleus (N) and lysosomes(LY). (Scale bar, $2 \mu \mathrm{m})$. (b) the basal lamina (BL), mitochondria (M) and vacuoles (V). (Scale bar, 500 $\mathrm{nm}$ ). (c) microvilli (MV) and the goblet cells (GC). (Scale bar, $500 \mathrm{~nm}$ ). 
Citation: Abo-Eleneen RE, El- Bakry AM, Abdeen AM (2014) Ultrastructural Study of the Alimentary Tract of Two Reptilian Species the Lizard Scincus scincus and the Snake Natrix tessellata. J Cytol Histol S4: 010. doi:10.4172/2157-7099.S4-010
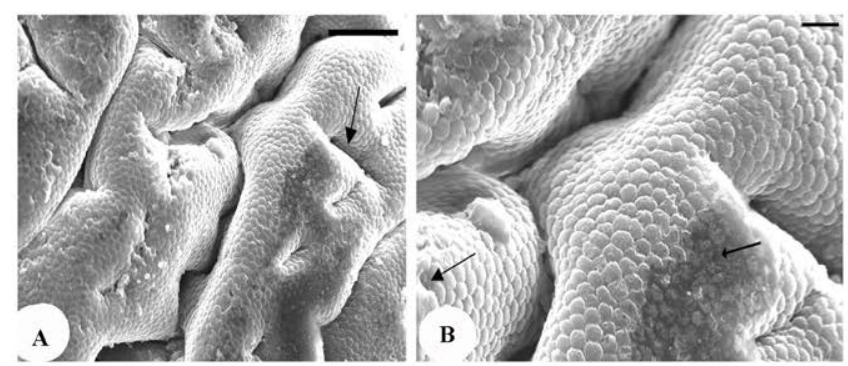

Figure 5: SEM micrograph of the stomach of Scincus scincus, showing (a) primary longuitudinal folds and the luminal surface of epithelial cell represented by pentagonal elevations, Note many gastric crypts appeared (arrow) (Scale bar, $50 \mu \mathrm{m}$ ). (b) the presence of gastric pit (arrow). (Scale bar, $10 \mu \mathrm{m})$.
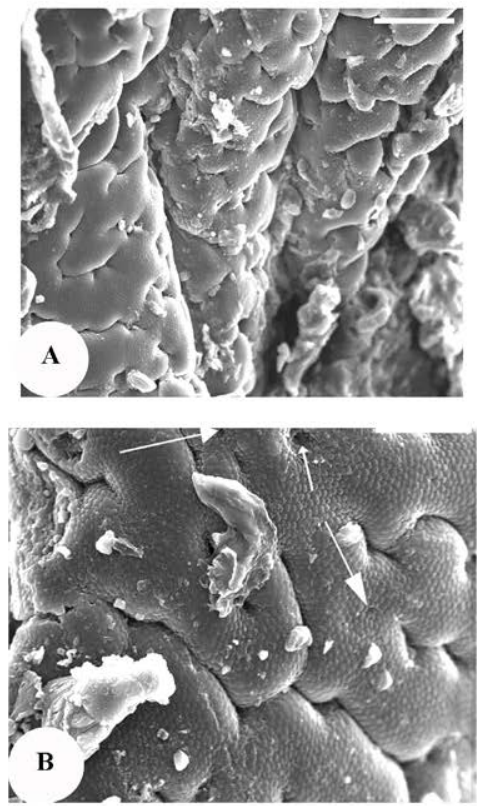

Figure 6: SEM micrograph of the stomach of Natrix tessellate showing (a) various folds and the luminal surface of epithelial cells with pentagona and hexagonal elevations (Scale bar, $100 \mu \mathrm{m}$ ). (b) gastric pit (arrows) and crypts of the gastric glands. (Scale bar, $50 \mu \mathrm{m}$ ).

observation, and the luminal surface of columnar cells was pentagonal in shape and the gastric glands open into gastric crypts in the stomach (Figure 5a). Many gastric pits were also observed (Figure 5b).

In N. tessellata, under low magnifications of SEM, the mucosal surface of stomach was seen to form various folds forming many discrete but irregular pockets (Figure 6a). Under higher magnifications, it was found to be divided into pentagons and hexagons (Figure 6a and $6 \mathrm{~b})$. These correspond to the luminal surface of the epithelial cells. Occasional presence of prominent gastric pits surrounded by the epithelial cells was detected in this region (Figure 6b). Many gastric crypts were appeared in which gastric gland open (Figure 6b).

The mucosal cells of stomach of $S$. scincus, containing spherical secretory Granules that filled with homogenous material (Figure 7a). A euchromatinic nucleus, endoplamic reticulum, vacuoles, lysosomes and many small mitochondria were also observed (Figure $7 \mathrm{~b}$ and $\mathrm{c}$ ). While in $N$. tessellata, the epithelium of the stomach has numerous mucinogen granules (Figure 8a). The epithelial cells appeared with oval euchromatinic and irregular nucleus with a large nucleolus, vacuoles, numerous mitochondria and lysosomes were also seen (Figure $8 \mathrm{~b}$ and $8 c)$.

In S. scincus, Under scanning electron microscope, there was many primary folds of intestinal mucosa extends along the entire length of the intestinal tract and it observed projecting into the lumen without

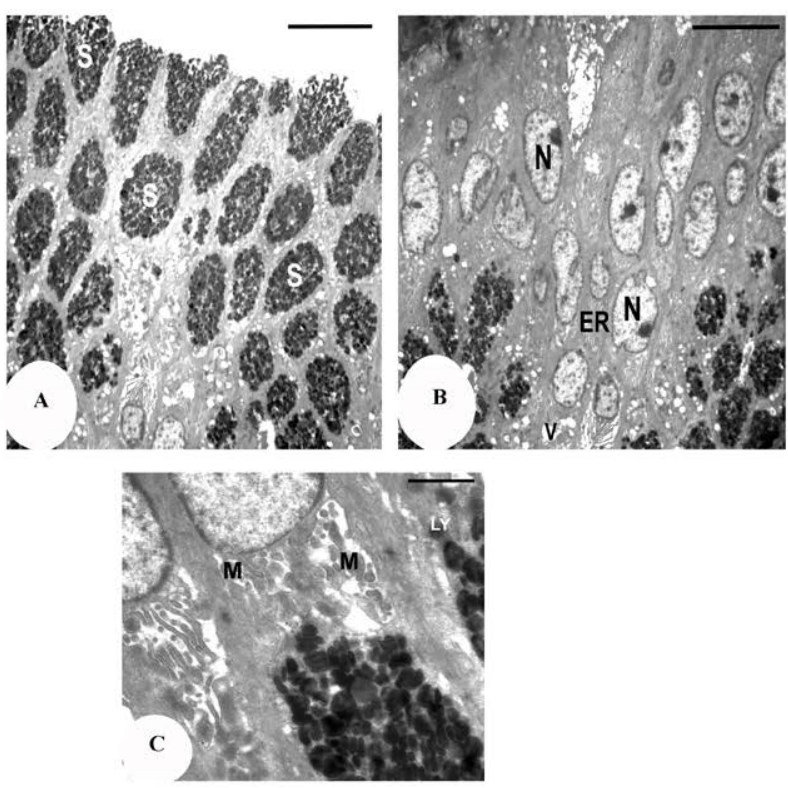

Figure 7: TEM micrograph of the stomach mucosal cells of Scincus scincus, showing (a) numerous electron dense secretory granules (S).

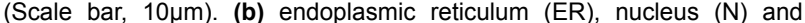
vacuoles $(\mathrm{V})$. (Scale bar, $10 \mu \mathrm{m})$. (c) Golgi apparatus (GA), mitochondria (M) and lysosomes (LY). (Scale bar, $2 \mu \mathrm{m}$ ).
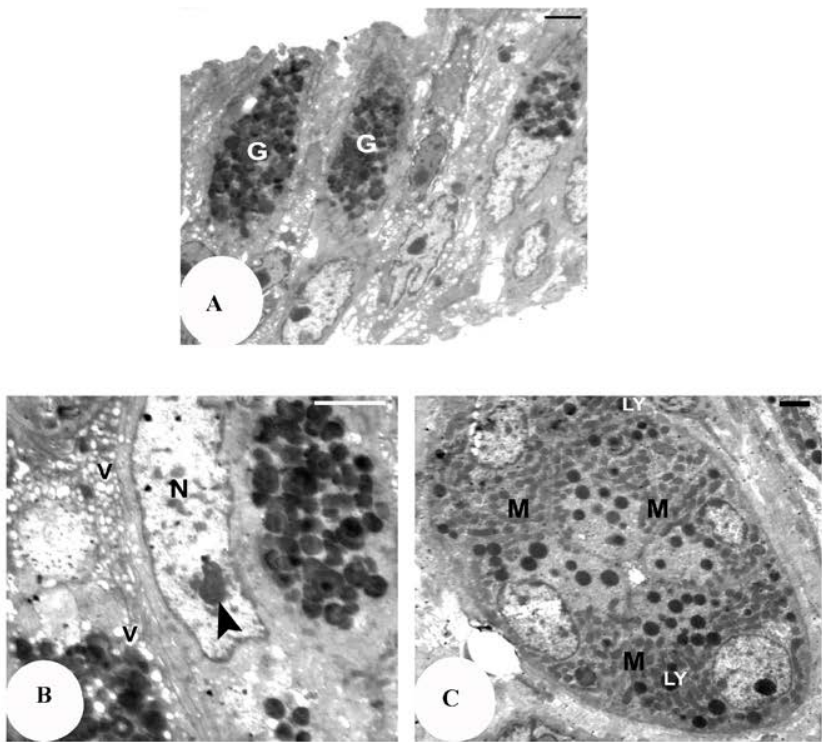

Figure 8: TEM micrograph of the stomach mucosal cells of Natrix tessellata, showing (a) numerous granules (G). (Scale bar, $2 \mu \mathrm{m}$ ). (b) vacuoles $(\mathrm{V})$ and the basal position of the nucleus $(\mathrm{N})$ with a prominent nucleolus (arrowhead). (Scale bar, $2 \mu \mathrm{m}$ ). (c) numerous mitochondria (M) and lysosomes (LY). (Scale bar, $2 \mu \mathrm{m})$. 
Citation: Abo-Eleneen RE, El- Bakry AM, Abdeen AM (2014) Ultrastructural Study of the Alimentary Tract of Two Reptilian Species the Lizard Scincus scincus and the Snake Natrix tessellata. J Cytol Histol S4: 010. doi:10.4172/2157-7099.S4-010

Page 4 of 7
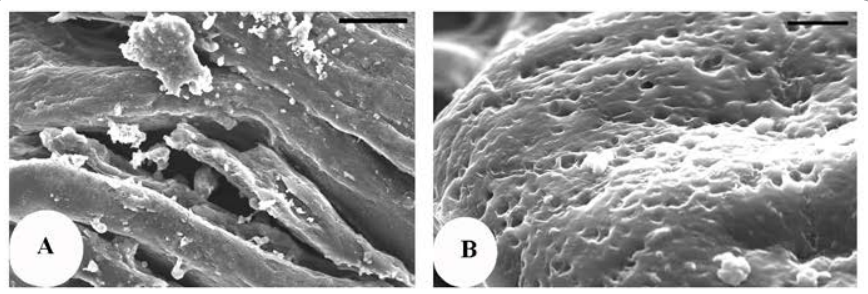

Figure 9: SEM micrograph of the intestine of Scincus scincus, showing (a) primary folds. (Scale bar, $100 \mu \mathrm{m}$ ). (b) scattered goblet cells (Scale bar, $20 \mu \mathrm{m})$.

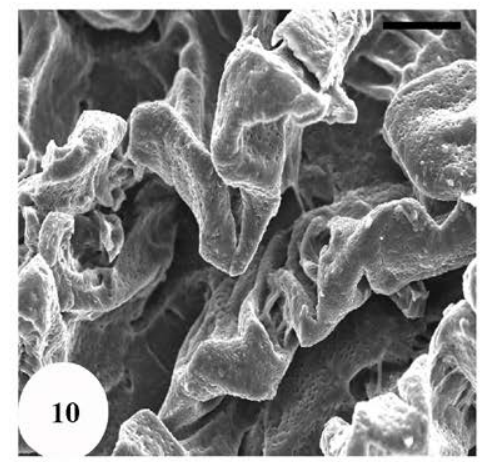

Figure 10: SEM micrograph of the intestine of Natrix tessellata, Note wavy longitudinal secondary mucosal folds. (Scale bar, $100 \mu \mathrm{m}$ ).
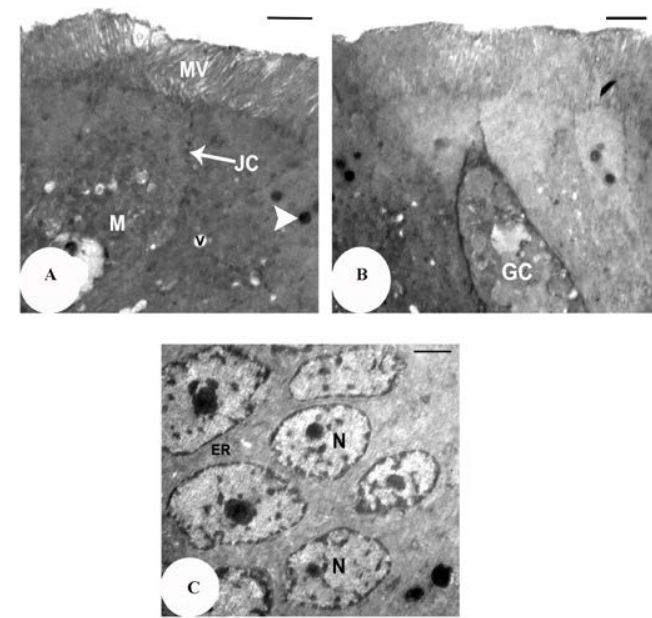

Figure 11: TEM micrograph of the intestine mucosal cells of Scincus scincus, showing (a) microvilli (MV), mitochondria (M) and lysosomes (arrow head). Note also, the junctional complexes (JC) situated just below the free surface. (Scale bar, $2 \mu \mathrm{m}$ ). (b) goblet cell (GC). (Scale bar, $2 \mu \mathrm{m}$ ).

(c) Euchromatic nucleus (N). (Scale bar, $2 \mu \mathrm{m}$ ).

following a definite pattern in their orientation and many goblet cells observed (Figure 9a and 9b). While the most characteristic feature of the intestine in $N$. tessellata is the presence of irregular, wavy longitudinal secondary mucosal folds in the fashion of Zig-Zag pattern enclosing a number of concavities in between them (Figure 10). Each species have many scattered goblet cells and lacks granular crypts.
At ultrastructural level, the columnar cells of the intestine of $S$. scincus have many mitochondria and microvilli toward the lumen and are joined together at the apical surface by junctional complexes. Lysosomes, vacuoles and mitochondria are scattered in the supranuclear cytoplasm of the enterocyte (Figure 11a). Goblet cells are seen near the luminal surface of intestinal epithelium (Figure 11b). A basal nucleus with a large nucleolus and rough endoplasmic reticulum are seen in the enterocytes (Figure 11c). The mucosal cells in the intestinal epithelium of $N$. tessellata, are consisted of columnar cells bearing microvilli and joined at the apical surface by the junctional complex, including the evident desmosomes, their cytoplasm contains numerous mitochondria and lysosomal bodies (Figure 12a). Goblet cells appeared elongated (Figure 12b). The nucleus and vacuoles are seen in the enterocytes (Figure 12c).

\section{Discussion}

The structural organization of the digestive system of reptiles is similar to higher vertebrates. Among different reptiles, some adaptive modifications could be seen in alimentary tract, for instance, the epithelial layers in the esophagus of turtles are keratinized in order to protect the mucosa from abrasive diets $[5,11]$.

The results of the present work revealed some differences in the structure of the oesophagus of both species related to type of food and feeding habits of both species. The oesophageal mucosal surface in $S$. Scincus was provided with many prominent longitudinal folds while in $N$. tessellata, the oesophageal surfaces have primary longitudinal folds of different sizes and many secondary ramification. This result agree with that observed in Uromastyx aegyptius and Varanus niloticus
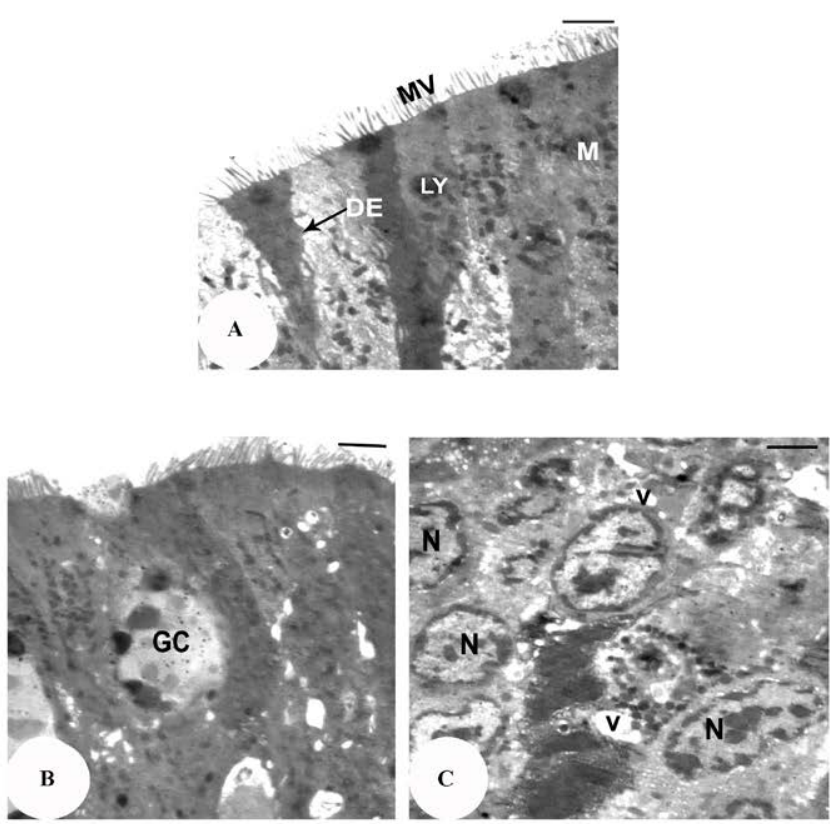

Figure 12: TEM micrograph of the intestine mucosal cells of Natrix tessellata, containing (a) microvilli (MV) covering the surface of the intestine in a regular manner, lysosomes (LY), desmosomes (DE) and abundant mitochondria (M). (Scale bar, $2 \mu \mathrm{m})$. (b) goblet cell (GC). (Scale bar, 2 $\mu \mathrm{m})$. (c) vacuoles $(\mathrm{V})$ and irregular shape of nucleus $(\mathrm{N})$. (Scale bar, $2 \mu \mathrm{m}$ ). (arrow head). Note also, the junctional complexes (JC) situated just below the free surface. (Scale bar, $2 \mu \mathrm{m}$ ). (b) goblet cell (GC). (Scale bar, $2 \mu \mathrm{m}$ ). (c) Euchromatic nucleus (N). (Scale bar, $2 \mu \mathrm{m})$. 
$[6,12]$. This feature is common for the reptiles, Uromastyx philibyi [13] and Pristurus rupestris [14]. The esophagus of the crocodile $C$. crocodilus yacare [15] and C. latirostris [16] has longitudinal folds in the esophageal mucosa.

The esophagus lumen of the cranial portion in the Japanese lizard has no fold. However, the middle and caudal portions are formed of very complicated folds [17]. This folds are totally distensible, to enable expansion of the esophagus, allowing it to store food that is ingested [15].

In catfish, the anterior part of the oesophagus was characterized by the presence of numerous mucosal folds that may allow maximal distension for prey and broken down food, the oesophagus of carnivorous fish acted as a constitutive adaptation that protected the oesophagus against live prey damages [18].

Our results revealed that the oesophagus of both species possessed a high density of goblet cells. The presence of the goblet cells in the oesophageal mucosa of Natrix tessellata as well as of other reptiles, such as Ablephorous pannonicus [19], Chamaeleon vulgaris [20] and $U$. philbyi [13], agrees with the basic task of the oesophagus which conveys food from the buccal cavity to the stomach. This function is facilitated by the mucous secretion of the goblet cells, which causes the inner surface of the oesophageal lumen to be viscous and thus facilitates the swallowing of the prey and it's gliding through the oesophageal lumen to reach the stomach. In Uromastyx aegyptica, the goblet cells of the esophagus are rich in acid mucopolysaccharides when compared to the small and large intestines [12].

The increased number of goblet cells in the oesophagus of all fish species in general was probably due to the absence of salivary glands, as the mucin excreted in the oesophagus and buccal cavity compensates the absence of salivary glands in fish [21].

In the present species S. Scincus, The oesophageal mucosal epithelial surface contain many well-defined wavy micriridges while in $N$. tessellata it provided with fingerprint-like microridge alternates in some region with microvilli. Microridges by virtue of their nature would seem to spread and hold mucus film secreted by the adjacent goblet cells [22]. Microridges have also been reported to be present on various epithelial surfaces, such as skin [23], gills [24], which are subject to mechanical stress. This would appear to be an advantage in having a sculped surface for absorbing impacts [22]. The superficial cell layer the oesophageal epithelium in catfish, provided with microvilli that indicates an adaptation to rapid ion absorption [25] while the presence of fingerprint-like microridges may represent a mechanical adaptation that would withstand the trauma resulting from ingesting bulky materials [26]. The fingerprint-like microridges observed on the esophageal surface cells in $N$. tessellata are similar to those reported in Solea senegalensis [27], in Dentex dentex [9], in Seriola dumerilli [28], in Rita rita [29], and in several other seawater and freshwater fishes [25]. These ridges have been thought to play an important role of protecting the buccal-oesphageal surface from trauma and providing an anchor to the mucus secreted from the goblet cells [30].

The oesophageal mucosal cells of the present $S$. scincus, showed the presence of oval-shaped nucleus, the perinuclear cytoplasm contained mitochondria, few rough endoplasmic reticulum, lysosomes, few electron light vesicles and numerous goblet cells are found in the mucosa of stratified epithelium occupying the whole length of the oesophagus. These observations are similarly met with in Micropogonias furnieri [31], in Uromastyx aegyptius [6] and in Scincus scincus [8]. While, the mucosal cells of oesophagus in $N$. tessellata, are columnar cells with basal microvilli. The surface epithelial cells showed large nucleus, vacuoles, endoplasmic reticula, lysosomes and numerous mitochondria scattering in their cytoplasm. These cells are probably adapted for ingestion of small fishes and other small aquatic animals. The goblet cells which arranged in the oesophageal epithelia are important for rapid and consistent lubrication of food particles during swallowing [6,32]. In some reptiles, the stratified and squamous epithelial layers of the esophagus are similar to mammals; however, some typical modifications were also noted for different species [5] such as Varanus niloticus which had columnar epithelia [33]. In lizards, it is formed of folds lined by ciliated columnar epithelium with goblet cells. Some snakes have mucous glands along their submucosa [5]. The esophageal mucosa of Lacerta agilis and Ophisops elegans is composed of ciliated columnar and goblet cells [34,11].

In some lizards such as Tachysaurus rugosus, Tiliqua nigrolutea [35] and Acanthodactylus boskianus [14] many esophageal glands have been observed although the esophagus of crocodilian Caiman latirostris does not have submucosal glands in submucosa, but only intraepithelial glands [16].

In the present study, as examined by SEM, the stomach of S. scincus had a meshwork of primary folds. The luminal surface of columnar cells was pentagonal and with many gastric pits. While in N. tessellata, the mucosal surface of stomach was form various folds forming many discrete but irregular pockets and a prominent gastric pits appeared. This observation agrees with that done on Salmo gairdneri [36], in Mystus aor [22], and in Rhamdia quelen [37]. In Lates niloticus, the complex foldings of stomach may probably provide for the extension of the stomach capacity during ingestion and increase the surface area during digestion [38]. The complex nature of folding in stomach wall would probably allow for stretching during food consumption and also increase surface area for digestive activity [22]. Grau et al. [28] found that the stomach of Seriola dumerilli displayed a large number of primary longitudinal folds which contained secondary folds.

But the cardiac surface of $O$. angorae is a meshwork of primary folds; the fundic and pyloric surfaces have many deep regular longitudinal folds with transverse secondary folds [39].

Our result in the present species, $N$. tessellata, showed that the gastric glands open into gastric crypts in the stomach. This result as that observed in many fishes that are bottom feeders [40], and they were also related to digestion time, and to carnivorous and voracious feeding [41]. The secretions of the gastric glands probably protect the mucosa from the acidic contents of the stomach as in O. angorae [39]. According to Martin and Blaber [42], gastric glands in Ambassidae were packed beneath the epithelial layer, but the epithelium did not have goblet cells.

The fine structure of gastric cells of $S$. scincus, showed that the apical part of cytoplasm contained variable numbers of secretory granules, vacuoles, lysosomes and many small mitochondria. Similar observations were recorded by Abo-Eleneen, Biomy [6,8]. While the mucosal cells in the stomach of $N$. tessellata, contain mucinogen granules. These mucinogen granules are discharged from the columnar cells to the surface of the mucosa; they form a layer of adherent membrane protecting the mucosa which is similar to that found in the soft-shelled turtles that have similar food interest as Varanus niloticus [43]. The mucinogen granules of Natrix tessellata, were found also in fishes, amphibians and birds [44]. In the present study, the endoplasmic reticula, lysosomes and vacuoles of the epithelial columnar cells are nearly similar to those of some carnivorous fishes such as Channa argus, Parasilurus asotus, Pelteobagrus fulvidraco [45] and in Varanus niloticus [6]. 
Citation: Abo-Eleneen RE, El- Bakry AM, Abdeen AM (2014) Ultrastructural Study of the Alimentary Tract of Two Reptilian Species the Lizard Scincus scincus and the Snake Natrix tessellata. J Cytol Histol S4: 010. doi:10.4172/2157-7099.S4-010

In the present study, SEM observation showed that the intestinal mucosa of S.scincus has primary folds along the entire length of the intestinal tract. While in N. tessellata it appeared as wavy longitudinal secondary mucosal folds in the form of Zig-Zag pattern. Similar observations were reported by Jacobshagen, (1937) [46] on studing intestine of crocodiles and snakes. Zigzag longitudinal folds of the intestinal surface of the present study the same as reported by Clarke and Witcomb [47]. A great amount of folds were observed in loop I of the intestine of Trichomycterus brasiliensis, increasing the surface area, and enhancing the absorptive activity, typical for carnivorous species [48]. In Schizothorax curvifrons, the large intestine of is thrown into irregularly arranged mucosal folds, minor mucosal folds and the concavity being totally absent [49]. The intestinal mucosa of the present species lacks granular crypts. This outcome is closely similar to that recorded in both lacertilian and ophidian species [19].

The columnar cells of the intestine of $S$. scincus, have many mitochondria and microvilli located toward the lumen and are joined together at the apical surface by junctional complexes. Lysosomes, vacuoles, endoplasmic reticulum and mitochondria were scattered in the supra-nuclear cytoplasm. These ultrastructural observations confirm the earlier findings of Goro-Takahata [50] in Oryzias latipes, Banan khojasteh et al. [51] in Oncorhynchus mykiss, Dai et al. [52] in Monopoterus albus and Abo-Eleneen [6] in Uromastyx aegyptius.

The intestine of $S$. scincus contained goblet cells. These cells are similar to those described in fishes, amphibia, reptiles and mammals [53$55]$ and other reptiles [56,57]. The goblet cells contain mucosubstance mainly formed by carboxylated glycoconjugates [58].

At the ultrastructural level, the enterocytes of the epithelium of $N$. tessellate, showed regular microvilli to increase the surface area. The presence of microvilli and lysosomes in the apical region of the intestinal columnar epithelial cells play part in collection of the nutritive substances from the lumen and their intracellular digestion. The enterocytes are joined laterally near the free surface by junctional complexes. Similar observations were recorded by Caceci and Hrubec [59]. The goblet cells of the intestine of $N$. tessellate contained many mucosubstances and secrete more mucilage for efficient digestion. This finding is similar to that found in the rice field eel Monopterus albus [52], in other fish species [28,60-63] and in Varanus niloticus [6] and in Typhlopid Snake Rhamphotyphlops Braminus [7].

The presence of many mitochondria suggests that a high amount of energy is required for active transport. Similar observations were recorded by Arellano et al. and Alexandre et al. [64,65].

We can conclude from the present study that the ultrastructural differences in the alimentary tract among the two reptilian species examined exhibited important specific features reflecting the mode of life and feeding habits of these animals.

\section{References}

1. Delashoub M, Pousty I, Khojasteh, SM (2010) Histology of Bighead carp (Hypophthalmichthys nobilis) intestine. Global Vet 5: 302-306.

2. Putterill JF, Soley JT (2003) General morphology of the oral cavity of the Nile crocodile, Crocodylus niloticus (Laurenti, 1768). I. Palate and gingivae. Onderstepoort J Vet Res 70: 281-297.

3. Guibe J (1970) L'appareil digestif. In Traite de Zoologie (Ed. P.P. Grassé). Paris: Masson.

4. Parsons T, Cameron J (1977) Internal relief of the digestive tract. Biology of the Reptilia. Vol 6, Academic Press. New York.

5. Elliott JR (2007) Overview of Reptile Biology, Anatomy and Histology. Infections Diseases and Pathology of Reptiles. Brooklyn, New York, Taylor \& Francis Group.
6. Abo- Eleneen RE (2010) Comparative histological and histochemical studies on the mucosa of the digestive tract of the herbivore Uromasatyx aegyptius and the carnivore Varanus niloticus. J Egypt Ger Soc Zool 60 B: 1- 35.

7. Abdeen AM, Mostafa NA, Abo-Eleneen RE, Elsadany DA (2013) Anatomical Studies on the Alimentary Tract of the Egyptian Typhlopid Snake Rhamphotyphlops Braminus. Journal of American Science. 9: 504-517.

8. Biomy AA (2010) Ultrastructural and histochemical characterization of the alimentary tract of the insectivorous Scincus scincus (Scincidae). J Enviro Sci 39: 525- 545.

9. Carrassón M, Matallanas J (1994) Morphometric charateristics of the alimentary tract of deep - sea Mediterranean teleosts in relation to feeding habits. Mar Biol 118: 319-322.

10. Imtiyaz HM, Ashok C (2010) Histochemical Distribution of Lipase and Acid Phosphatase in the Intestinal Tract of the Snow Trout, Schizothorax curvifrons Heckel. J Biol Sci, 10: 643-647.

11. Çakici O, Akat E (2013) Some histomorphological and histochemical characteristics of the digestive tract of the snake-eyed lizard, Ophisops elegans Menetries, 1832 (Squamata: Lacertidae). North-Western J of Zoology 9: art.131507.

12. Zaher M, El-Ghareeb AW, Hamdi H, Essa A, Lahsik S (2012) Anatomical, Histological and Histochemical Adaptations of the Reptilian Alimentary Canal to Their Food Habits: I. Uromastyx aegyptiaca. Life Science Journal 9: 84-104.

13. Farag AA (1982) Histological studies on the mucosal epithelium of the agamid lizard, Uromastyx philbyi Parker Ann Zool, XIX: 1-23.

14. Dehlawi GY, Zaher MM (1985) Histological studies on the mucosal epithelium of the gecko Pristurus rupestris (Family Geckonidae). Proceedings of the Zoological Society. AR Egypt 9: 91-112.

15. Jin SM, Rodrigues CAT, Silva MP, Santos FR (1985) Observações morfológicas do esôfago do Caiman crocodilus yacare crocodilia-repitilia (Daudin,1802). Revista Brasileira de Ciências Morfológicas 2: 49-58.

16. Machado -Santos C, Zeca SG, Abidu-Figueiredo M, Ribeiro ICA, Sales A (2011) The esophagus of the crocodilian Caiman latirostris (Reptilia, Crocodylia) histological, histochemical and immunohistochemical study. J Morphol.Sci, 28 : 113-119.

17. Imai M, Shibata T, Izumi T (1992) Histological and histochemical investigations on Japanese lizard esophagus. Okajimas Folia Anat Jpn 69: 25-34.

18. Santos CM, Duarte S, Souza TGL, Ribeiro TP, Sales A, Ara'ujo FG (2007) Histology and histochemical characterization of the digestive tract of Pimelodus maculatus (Pimelodidae, Siluriformes) in Funil reservoir, Rio de Janeiro, Brazil, Iheringia, 97: 1-9.

19. Greschik E (1917) Uber den Darmkanal von Albepharus pannonicus Fritz, und Anguis fragilis L. Anat Anz 50: 70-80.

20. Bishai $H$ (1960) The anatomy and histology of the alimentary tract of Chamaeleon vulgaris Daud. Bulletin of the Faculty of Science, Cairo University 35: 44-61.

21. Marchetti L, Capacchietti M, Sabbieti MG, Accili D, Materazzi G, et al. (2006) Histology and carbohydrate histochemistry of the alimentary canal in the rainbow trout Oncorhynchus mykiss. Journal of Fish Biology 68: 1808-1821.

22. Sinha GM, Chakrabarti $P$ (2006) Scanning electron microscopic studies on the mucosa of the digestive tract in Mystus aor (Hamilton). Proc Indian Natn Sci Acad B52: 267-73

23. Hawkes JW (1974) The structure of fish skin. I. General organization. Cell Tissue Res 149: 147-158

24. Mattey DL, Morgan M, Wright DE (1980) A scanning electron microscope study of the pseudobranchs of two marine teleosts. J Fish Biol. 16: 331-343.

25. Meister MF, Humbert W, Kirsch R, Vivien-Roels B (1983) Structure and ultrastructure of the oesophagus in sea-water and fresh-water teleosts (Pisces). Zoomorphology 102: 33-51.

26. Abd El Hafez AE, Mokhtar MD, Abou-Elhamd SA, Hassan HA (2013) Comparative Histomorphological Studies on Oesophagus of Catfish and Grass Carp. Journal of Histology 1-10.

27. Arellano JM, Storch V, Sarasquete C (2001) A histological and histochemical study of the oesophagus and oesogaster of the Senegal sole, Solea senegalensis. Eur J Histochem 45: 279-294. 
Citation: Abo-Eleneen RE, El- Bakry AM, Abdeen AM (2014) Ultrastructural Study of the Alimentary Tract of Two Reptilian Species the Lizard Scincus scincus and the Snake Natrix tessellata. J Cytol Histol S4: 010. doi:10.4172/2157-7099.S4-010

28. Grau A, Crespo S, Sarasquete MC, Gonzales de Canales ML (1992) The digestive tract of the amberjack Seriola dumerili, Risso: a light and scanning electron microscope study. J Fish Biol 41: 287- 303.

29. Yashpal M, Kumari U, Mittal S, Mittal AK (2006) Surface architecture of the mouth cavity of a canivorous fish Rita rita (Hamilton, 1822) (Siluriforms, Bagridae). Belg J Zool 136: 155-62.

30. Wilson JM, Castro LF (2010) Morphological Diversity of the Gastrointestinal Tract in Fishes. In: Martin, G.; Farrel, A. P. \& Brauner, C. J. (Edn). The Multifuctional Gut of Fish.London, Academic Press.

31. Diaz AO, García AM, Figueroa DE, Goldemberg AL (2008) The mucosa of the digestive tract in Micropogonias furnieri: a light and electron microscope approach. Anat Histol Embryol 37: 251-256.

32. Albrecht MP, Ferreira MFN, Caramaschi EP (2001) Anatomical features and histology of the digestive tract of two related neotropical omnivorous fishes (Characiformes; Anostomidae). J Fish Biol 58: 419- 430.

33. Ahmed YA, El-Hafez AAE, Zayed AE (2009) Histological and histochemical studies on the oesophagus, stomach and small intestines of Varanus niloticus. Journal of Veterinary Anatomical 2: 35-48.

34. Przystalski A (1980) The dimensions of mucosa and the structure of the alimentary canal in some reptiles.Acad. Biologica Cracoviensia Series: Zoologia XXIII: 1-33.

35. Trethewie ER, Wright RD (1956) Histamine of the reptilian stomach and lung Nature 178: 546

36. Ezeasor DN, Stokoe WM (1980) Scanning electon microscopic study of the gut mucosa of the rainbow trout Salmo gairdneri Richardson. J Fish Biol, 17: 529-539.

37. Perez-Tomas R, Ballesta J, Madrid IF, Pastor LM, Hernandez F (1990) Histochemical and ultrastructural study of the digestive tract of the tortoise Testudograeca (Testudines). J Morphol 204: 235- 246.

38. Namulawa VT, Kato CD, Nyatia E, Rutaisire J, Britz P (2013) Scanning Electron Microscopy of the Gastrointestinal Tract of Nile Perch (Lates niloticus, Linneaus, 1758). Int J Morphol 31: 1068-1075.

39. Suíçmez M, Ulus E (2005) A study of the anatomy, histology and ultrastructure of the digestive tract of Orthrias angorae Steindachner, 1897. Folia Biol (Krakow) 53: 95-100

40. Bishop C, Odense PH (1966) Morphology of the digestive tract on the cod Gadus morhua. Fish Res Board Can 23: 1607-1615.

41. Moshin SM (1962) Comparative Morphology and histology of the alimentary canals in certain groups of Indian teleosts. Acta Zool 43: 79- 133.

42. Martin TJ, Blaber SJM (1984) Morphology and histology and of the alimentary tracts of Ambassidae (Cuvier) (Teleostei) in relation to feeding. J Morphology 182: 295-305.

43. Su ZH, Chen XW, Chen QS (2004) Ultrastructure of mucous membrane and glandular epithelium of stomach in soft-shelled turtle, Trionyx sinensis. J Nanjing Agric Univ 27: 139- 141.

44. Rebolledo IM, Vial JD (1979) Fine structure of the oxynticopeptic cell in the gastric glands of an elasmobranch species (Halaelurus chilensis). Anat Rec 193: 805-822.

45. Wang YM, Wang W (1989) Microscopic and ultramicroscopic studies on gastric gland cells of several freshwater fishes. Acta Hydrobiol Sin 13: 334- 339.
46. Jacobshagen E (1937) IV. Mittel und Enddarm (Rumpfdarm). In Handbuch der vergleichenden Anatomie der Wirbeltiere (Ed. L. Bolk, E. Kallius and W. Lubosch). Berlin: Urban \& Schwarzenberg. Anat. Jpn.69, 25-34.

47. Clarke AJ, Witcomb DM (1980) A study of the histology and morphology of the digestive tract of the common eel (Anguilla anguilla). Jour Fish Biol 16: 159-170.

48. Khanna SS, Mehrotra BK (1971) Morphology and histology of the teleostean intestine. Anat Anz 129: 1-18

49. Mir IH, Channa A (2010) A scanning electron microscopic examination of the intestinal tract of the snow trout, Schizothorax curvifrons Heckel.J. Fish Aquat Sci 5: 386-393.

50. Goro-Takahata (1981) Ultrastructure of the endocrine cells in the digestive organs of the medaka, Oryzias latipes. Jpn J Ichthyol 27: 4- 20.

51. Banan Khojasteh SM, Sheikhzadeh F, Mohammadnejad D, Azami A (2009) Histological, histochemical and ultrastructural study of the intestine of rainbow trout (Oncorhynchus mykiss). World Appl Sci 6: 1525- 1531.

52. Dai X, Shu M, Fang, W (2007) Histological and ultrastructural study of the digestive tract of rice field eel, Monopterus albus. J Appl Ichthyol, 23: 177- 183

53. Slijper EJ (1946) [Not available]. Tabulae Biol 21: 1-81.

54. Kendall JI (1947) Microscopic Anatomy of Vertebrates. 3rd Edn. Philadelphia: Lea \& Febiger.

55. Barrington EJW (1957) The alimentary canal and digestion. In: The Physiology of Fishes (Ed. M.E Brown). New York.

56. Vialli M (1929) Richerche Sull'intestino dei rettili. IV. L'epitelio intestinale. Archivio di Biologia, 39: 529- 581

57. Ferri S, Junqueira LC, Medeiros LF, Mederios LO (1976) Gross, microscopic and ultrastructural study of the intestinal tube of Xenodon merremii Wagler, 1824 (Ophidia). J Anat 121: 291-301.

58. Scocco P, Ceccarelli P, Lorvik S, Menghi G (1994) Istochimica dei carboidrat complessi nel canale alimentare di Tilapia Spp. Atti Vet, Vol. X VIII. 21- 39

59. Caceci T, Hrubec TC (1990) Histology and ultrastructure of the gut of the black mollie (Poecilia spp.), a hybrid teleost. J Morph 204: 265- 280.

60. Arellano JM (1995) Contribucion a la histologia, histoquimica e histopatologia de la dorada, Sparus aurata, L. Tesis de Licenciatura. Town: University of de Cádiz.

61. Sarasquete C, Polo A, Yúfera M (1995) Histology and histochemistry of the development of the digestive system of larval gilthead seabream, Sparus aurata L. Aquaculture 130: 79- 92.

62. Murray HM, Wright GM, Goff GP (1996) A comparative histological and histochemical study of the post-gastric alimentary canal from three species of pleuronectids, the Atlantic halibut, the yellow tail flounder and the winter flounder. J Fish Biol 48: 187- 206

63. Radaelli G, Domeneghini C, Arrighi S, Francolini M, Mascarello F (2000) Ultrastructural features of the gut in the white sturgeon, Acipenser transmontanus. Histol Histopathol 15: 429-439.

64. Arellano JM, Storch V, Sarasquete C (2002) Ultrastructural study on the intestine of Senegal sole, Solea senegalensis. J Appl Ichthyol 18: 154- 158.

65. Alexandre L, Cunha da, Batista C (2007) Ultrastructural, histochemical and cytochemical characterization on intestinal epithelial cells in Aplysia depilans (Gastropoda, Opisthobranchia). Acta Zool 88: 211- 221.
This article was originally published in a special issue, Histology and Histopathology handled by Editor(s). Borislav A. Alexiev, University of Maryland Medical Center, USA 